\title{
George Berkeley, Siris. tańcuch filozoficznych refleksji i dociekań wraz z Dodatkami, przeł. A. Grzeliński, M. Szymańska-Lewoszewska, Wydawnictwo Naukowe Uniwersyłetu Mikołaja Kopernika, Toruń 2013, ss. 288
}

DOI: http://dx.doi.org/10.12775/RF.2014.023

Polskie tłumaczenie Siris George’a Berkeleya - które do rąk czytelników trafiło ono latem 2013 roku - ma dla rodzimej humanistyki znaczenie podwójne. Przede wszystkim przekład ten dostarcza kolejnego dowodu na rzecz tezy o ożywieniu w polskim środowisku filozoficznym zainteresowania nowożytną myślą brytyjską. Zarazem publikację tę można uznać za swoisty probierz zaawansowania, a co za tym idzie świadectwo dojrzałości polskich badań nad spuścizną irlandzkiego biskupa. Siris, przetłumaczony przez Adama Grzelińskiego i Martę Szymańską-Lewoszewska, a wydany nakładem Wydawnictwa Naukowego UMK, wraz z dodatkami, na które złożyły się trzy listy Berkeleya do Thomasa Priora, list do doktora Halesa, oraz dwa inne pomniejsze dokumenty, należy bowiem do późnego okresu twórczości Berkeleya - jego pierwsza edycja na Wyspach Brytyjskich ukazała się w roku 1744, a więc aż 34 lata po opublikowaniu Traktatu o zasadach poznania ludzkiego (jedna z prac uzupełniających omawiane wydawnictwo, zatytułowana Dalsze rozważania o wodzie dziegciowej, jest ostatnim w ogóle tekstem napisanym przez Berkeleya!). Przekład Siris można więc zasadnie uznać za swego rodzaju dopełnienie i ukoronowanie podejmowanych w ostatnich latach wysiłków na rzecz przybliżenia polskiemu audytorium filozoficznemu dorobku irlandzkiego biskupa.

Czas powstania dzieła, moment, w którym Berkeley podejmuje trud spisania zawartych w nim refleksji, odciska wyraźne piętno na treści traktatu. Wprawdzie zasadnicza ciągłość myśli Irlandczyka, zarówno w warstwie teoretycznej, jak i - bodaj jeszcze wyraźniej - stylistycznej, jest w nim nadal łatwo wyczuwalna. W swej naturze jest jednak Siris pismem osobnym, odmiennym, zwłaszcza w zestawieniu ze słynnymi, młodzieńczymi pracami Berkeleya. Inne są jego źródła inspiracji, inne przyświecają mu cele. Od pierwszych stron znać też, że mamy do czynienia z dziełem późnym. W swej osnowie stanowi ono bowiem przede 
wszystkim fascynujący zapis intelektualnego powrotu do źródeł. Tego rodzaju podróż należy zaś do przywilejów umysłowości dojrzałej, która - pomna złożoności wszelkich, zwłaszcza fundamentalnych problemów - nabyła już świadomego szacunku dla dorobku tradycji. W konsekwencji autor Siris w niczym nie przypomina młodego szermierza, który w Dziennikach gorączkowo szlifował polemiczne ostrze, a w Traktacie i Trzech dialogach zapamiętale fechtował z materializmem, sceptycyzmem, ateizmem i wszelką bezbożnością. I rzecz nawet nie w tym, że z upływem lat jego pióro stępiało, a spojrzenie straciło dawny ogień i przenikliwość - do śmierci pozostał bowiem Berkeley typem intelektualnego zapaleńca. Jeśli jego temperament polemiczny rzeczywiście osłabł, refleksja nabrała perspektywy, a osąd zyskał głębsze historyczne zakorzenienie - lektura Siris niezaprzeczalnie skłania zaś do takiego wniosku - dokonało się to raczej na skutek wieloletnich studiów, intelektualnego okrzepnięcia i żmudnego pogłębienia wiedzy. Znaczenie miała też zapewne specyfika podjętego tematu. O ile nowość problematyki, wespół z zaaferowaniem pierwszym, znaczącym odkryciem, usprawiedliwiały pośpiech i lekceważenie filozoficznej tradycji, naznaczające styl wczesnych prac Berkeleya, w których wykładał on swe immaterialistyczne credo, o tyle realizacja idei przedstawienia metafizycznej architektoniki natury $\mathrm{w}$ całej jej złożoności wymagała sięgnięcia po inny typ refleksji i wybrania innych towarzyszy podróży. Do urzeczywistnienia tamtego zamierzenia wystarczał patronat Descartesa, Nicolasa Malebranche'a i Johna Locke'a. Na sztandarach ówczesnej filozofii wciąż jeszcze powiewały zresztą kartezjańskie hasła nowego otwarcia i „wywietrzenia" zatęchłej doktryny szkół. Nowe rozważania potrzebują nowego przewodnika. Partnerem prowadzonych na kartach Siris dociekań siła rzeczy staje się więc antyk. W dziele raz po raz padają wielkie imiona, których próżno było szukać w pracach, bądź co bądź, młodego wykładowcy greki: Arystotelesa, Proklosa, Jamblicha, Augustyna, Cycerona, Hipokratesa, Hermesa Trismegistosa, a nade wszystko Platona i Plotyna. Krótko mówiąc, autor pisanego z mozołem Siris to już ktoś zupełnie inny niż porywczy młodzieniec rzucający na papier tezy Traktatu. Teraz usiłuje on raczej wspiąć się na ramiona gigantów, niż ostukiwać ich nogi w poszukiwaniu glinianych spojeń.

Recepcja Siris toczyła się zmiennymi kolejami. Pismo nie miało szczęścia do wyważonych ocen. Obok afektowanych pochwał spadła na nie lawina drwin i uszczypliwych komentarzy za sprawą domniemanego niezdrowego zaprzątnięcia zagadnieniem wody dziegciowej. W znacznej mierze była to krytyka niezasłużona, wynikła z niezrozumienia właściwej struktury dzieła. Ordo cognoscendi nie pokrywa się bowiem w Siris $\mathrm{z}$ ordo essendi. Wręcz przeciwnie, przyjęty przez Berkeleya porządek narracji odwraca odmalowany w dziele porządek natury. Siris należy więc czytać niejako od tyłu. Snując swe rozważania, Berkeley obiera bowiem 
synoptyczny tok wywodu - wznosi się od kluczowego konkretu (rolę tę odgrywa właśnie woda dziegciowa), poprzez eteryczne medium, ku Bogu - najwyższej zasadzie. Rusztowania teoretycznego dostarcza metafizyce Siris neoplatonizm. Nakreślona w piśmie architektonika rzeczywistości ma więc trójdzielną naturę. Centralną rolę w strukturze zarówno świata, jak i dzieła odgrywa subtelna i niedostrzegalna zmysłami substancja, określana przez Berkeleya mianem eteru, ognia bądź światła. Przenika on całą rzeczywistość: „niestrudzony, wciąż w ruchu, wprawia w działanie i ożywia wszelkie widzialne ciała, zdolny jest zarówno do tworzenia, jak i niszczenia [...] podtrzymuje ciągły obieg narodzin i zniszczeń, brzemienny formami, które ciągle wytwarza i z powrotem wchłania" (par. 152). Poświęcone eterowi rozważania prowadzi Berkeley niejako dwutorowo - na płaszczyźnie fizycznej i metafizycznej. W efekcie jego wywód wpisuje się w ramy owego charakterystycznego dla epoki dyskursu rodzącej się nauki i zanikającej alchemii, z domieszką filo- i teozoficznie pojętej metafizyki, który z taką lubością badali Gaston Bachelard i Michel Foucault. W swej istocie jest więc czystej wody produktem oświecenia - owego inkubatora nowożytnej cywilizacji naukowej, przekształcającego się już powoli w laboratorium, wciąż jeszcze pozostając gabinetem osobliwości. Przedstawiając swą hipotezę eteru, nieustannie odwołuje się tedy Berkeley do odkryć współczesnej mu nauki: badań Isaaca Newtona, Hermana Boerhaave'go, Roberta Boyle'a czy Wilhelma Homberga. Stosuje przy tym metodę przećwiczoną z sukcesem we wcześniejszych pracach. Wyłuskuje i interpretuje dosłownie wszystkie wyniki świadczące na korzyść jego teorii, instrumentalizując pozostałe elementy referowanych koncepcji. Równolegle stale rozwijany jest wywód metafizyczny. Sposób jego prowadzenia może jednak zaskakiwać. Berkeley niejako skrywa się za doktryną starożytnych, ograniczając się zazwyczaj do samego przytoczenia świadectw antycznych. Sugestia, że antycypują one i wspierają jego własne poglądy narzuca się sama przez się. A jednak kiedy tylko może, Irlandczyk unika wypowiedzenia jej wprost. Autor Siris jest znacznie ostrożniejszy od młodego autora Traktatu, bo i stąpa teraz po bardziej grząskim gruncie.

Nawiązując do myśli starożytnej, a zarazem wciąż jeszcze poruszając się $\mathrm{w}$ ramach paradygmatu średniowiecznej alchemii i medycyny, Berkeley kreśli obraz makrokosmosu na obraz i podobieństwo mikrokosmosu - istoty żywej. Wprost odwołuje się przy tym do antycznej wizji świata jako żywego zwierzęcia. W konsekwencji rzeczywistość uzyskuje w Siris organizację dualistyczną - duchowo-cielesną. Zarazem, co ważniejsze, wyłożona $\mathrm{w}$ piśmie doktryna ma charakter organicystyczny. Świat nie jest chaotycznym konglomeratem obiektów, lecz żywa, harmonijną strukturą - układem wzajemnie powiązanych członków, zespolonych w jeden organizm i zawiadywanym, jak każde żywe stworzenie, przez jedną życiodajną zasadę - duszę. Funkcję tej ostatniej 
pełni w doktrynie Siris właśnie ów, wspominany już, niewidzialny eter czy też ogień, który przenikając wszystkie rzeczy, obdarza je życiem, zawiaduje kierunkiem zachodzących $\mathrm{w}$ nich procesów, reguluje ich funkcjonowanie i w konsekwencji zespala całość stworzenia $\mathrm{w}$ jeden organiczny byt. A ponieważ ów płomień życia uobecnia się ze szczególną intensywnością w wodzie dziegciowej, właśnie w niej upatruje Berkeley swoistego panaceum - cudownego lekarstwa na wszelką dysharmonię i witalne niedomagania. Ostatecznie, przed oczyma czytelnika Siris wije się przeto, niczym tytułowy Nil, wielki łańcuch stworzeń, tekstualnie odwzorowany czy też zdublowany na kartach owego Łańcucha filozoficznych refleksji i dociekań, w którym Berkeleyowska idea semiotyki natury osiąga swoiste apogeum, urzeczywistniając się jako gąszcz odniesień i autoodniesień, możliwych jedynie w epoce, której symbolu upatrywano (Foucault) w Las Meninas Diego Velázqueza. I tak jak tekstem kieruje jedna przewodnia myśl filozoficzna, kosmosem Siris zawiaduje jedna rozumność, manifestująca się przez wszechprzenikające działanie eteru. Paralela z myślą antyczną narzuca się sama przez się. Toteż tekst skrzy się odniesieniami do starożytnych - Heraklita z jego światem ciągłych przemian ognia, sterowanych przez boski logos; stoików z ich pankosmiczną rozumnościa, Platona etc. Zarazem Berkeley unika prostego panteizmu. Choć ideę immanentnej jedności natury traktuje nadzwyczaj poważnie i wygłasza dobitnie, nie wahając się przywołać na świadka nawet Parmenidesa (par. 287), eteryczną anima mundi odróżnia wyraźnie od zawiadującego kosmosem Umysłu. Życiodajny eter, ogień, światło pozostaje więc ostatecznie tylko ogniwem pośrednim między światem doświadczenia a zawiadującą nim Opatrznością. Wpływ Boga na świat zostaje po prostu w systemie Siris zmediatyzowany - oto właściwa funkcja eteru. Otwarte pozostaje co najwyżej pytanie, czy doktryna ta nie zbliża się niebezpiecznie do emanacjonizmu (zob. np. par. 362).

Nakreślona z takim rozmachem trójdzielna gradacja rzeczywistości, postępująca od poziomu umysłowego, poprzez duchowy aż do cielesnego, musi rodzić pytanie o relację przedstawionej w Siris metafizyki do wcześniejszych ustaleń Berkeleya, w tym zwłaszcza jego immaterializmu. Próba udzielenia jakiejkolwiek jednoznacznej odpowiedzi w tej kwestii jest oczywiście obarczona ogromnymi trudnościami. Natura podejmowanej problematyki i sposób jej prezentacji może wywoływać wrażenie, że w nowej metafizycznej kompozycji immaterializm co najmniej stracił na znaczeniu. Zwolennicy pełnej ciągłości Berkeleyowskiej myśli znajdą jednak niewątpliwie w Siris wystarczająco wiele argumentów na poparcie swojego poglądu (zob. choćby par. 311, 319). Na podkreślenie zasługuje przede wszystkim niezmiennie ściśle instrumentalistyczna koncepcja praw natury, zwłaszcza mechanizmu powstawania wrażeń zmysłowych, oraz krytyka mechanicyzmu. Najprawdopodobniej Berkeley ponownie sięga więc do metody wykorzystanej po raz pierwszy już 
w Próbie stworzenia nowej teorii widzenia. Posługuje się dwoma systemami pojęciowymi, skorelowanymi z dwoma językami opisu: potocznym, $\mathrm{z}$ zawartą w nim sugestią pozaumysłowego istnienia i mechanicznej organizacji postrzeganej rzeczywistości, oraz ściśle filozoficznym, wykluczającym absolutna, realną egzystencję i aktywność czegokolwiek poza substancją duchową (vide np. par. 155). W tym duchu eter charakteryzuje więc np. jako naczelną naturalną przyczynę sprawczą tylko po to, by od razu doprecyzować, że $\mathrm{w}$ istocie jest on jedynie przyczyną instrumentalną - narzędziem Opatrzności (par. 152-161).

Kilka słów warto na koniec poświęcić stronie redakcyjnej omawianej publikacji. Na szczególną uwagę zasługuje klasa przekładu, opracowania i edycji tekstu Berkeleya. W tym kontekście kluczowe znaczenie ma okoliczność, że niełatwego zadania przybliżenia polskiemu czytelnikowi najbardziej niezwykłego, ale i najbardziej zawiłego dzieła brytyjskiego empiryzmu podjęli się znakomici i kompetentni tłumacze: profesor Adam Grzeliński, znawca, badacz i zasłużony tłumacz brytyjskiej myśli filozoficznej, autor pierwszej polskiej monografii poświęconej immaterializmowi Berkeleya, która wpisuje się $\mathrm{w}$ aktualny międzynarodowy stan badań nad tą problematyka, oraz dr Marta Szymańska-Lewoszewska, autorka nowatorskich publikacji z zakresu Berkeleyowskiej myśli politycznej i społecznej. W wyniku ich pracy powstał przekład znakomity, w pełni spełniający współczesne międzynarodowe standardy warsztatowe, zarówno pod względem formalnym, jak i merytorycznym. W rezultacie do rąk czytelnika trafia dzieło drobiazgowo opracowane, spójne kompozycyjnie i konceptualnie. Wrażenie to potęguje dodatkowo rozbudowany aparat krytyczny - obfite przypisy i komentarze oraz dodatki uzupełniające przekład głównego dzieła (zwłaszcza Berkeleyowska korespondencja), umożliwiają osadzenie lektury Siris w kontekście współczesnych mu dociekań, zmagań i polemik, ułatwiając czytelnikowi odnalezienie się $\mathrm{w}$ prawdziwym gąszczu filozoficznych, medycznych, chemicznych i fizycznych spekulacji. Dzieło poprzedzone zostało nadto obszernym wstępem, pełniącym funkcję swoistego przewodnika po późnej filozofii Berkeleya. Zarazem w warstwie terminologicznej tłumaczenie Siris w rzadko spotykany sposób łączy dbałość o szczegół i wierność translatorską z potoczystością i adekwatnością stylistyczną, a język przekładu doskonale oddaje ducha i kontekst intelektualny dzieła, nie przesłaniając jego warstwy treściowej. Ze wszystkich tych względów publikację Siris należy uznać za ważne wydarzenie w historii polskich zmagań z nowożytną myślą brytyjską. 